\title{
The conservation state of the Sassi of Matera site (Southern Italy) and its correlation with the environmental conditions analysed through spatial analysis techniques
}

\author{
F.T. Gizzi ${ }^{1 *}$, M. Sileo ${ }^{1}$, M. Biscione ${ }^{1}$, M. Danese ${ }^{1}$, M. Álvarez de Buergo ${ }^{2}$ \\ ${ }^{1}$ Institute for Archaeological and Monumental Heritage, Italian Research Council (CNR), Potenza, \\ Italy, f.gizzi@ibam.cnr.it*; m.sileo@ibam.cnr.it;m.biscione@ibam.cnr.it;m.danese@ibam.cnr.it; \\ ${ }^{2}$ Institute of Geosciences IGEO (CSIC,UCM). Spanish Research Council (CSIC) and Complutense \\ University of Madrid. Jose Antonio Novais 12, 28040 Madrid, Spain, alvarezm@geo.ucm.es
}

\begin{abstract}
The current study aims to analyse the conservation state of the Sassi of Matera site (Southern Italy), a place inscribed on the UNESCO World Heritage List since 1993 (The Sassi and the Park of the Rupestrian Churches of Matera) and recently awarded 2019 European Capital of Culture. Furthermore, the article considers the influence of some of the causative factors controlling the Matera building conservation state, paying particular attention to the site microclimatic conditions such as the insolation and winds. We studied this subject through a new methodology that makes a combined use both of stone decay data gained from the extensive field assessments of the visible weathering forms catalogued in an ad-hoc questionnaire and GIS advanced spatial analysis techniques such as Map Algebra and Kernel Density Estimation.

The research puts into evidence that the Sassi of Matera shows a fair state of conservation that is conditioned by the wind/rain actions and sun exposure. Besides, just the already well known facts that the surfaces facing north seem to be most influenced by the wind/rain actions; and that, on the contrary, the decay of the walls facing south seems to be guided mainly from the sun exposure, put into evidence the importance of locating the intensities of the decays in any urban tissue or any site in order to plan conservation interventions and prioritize actions and the usefulness of the spatial analysis techniques and data processing.
\end{abstract}

Keywords: decay index, conservation state, historical centre, spatial analysis, Kernel density

\section{Research aims}

The key aim of the paper is to discuss the present state of conservation of an important historical centre of Southern Italy, the Matera UNESCO site. In addition, the article aims to analyse, at the territorial scale, the relationship between the weathering forms observed on the buildings and the microclimate factors typical of the place, specifically insolation and wind.

In order to classify all the degradations affecting the Matera cultural stone we drew up a site-specific questionnaire grouping decay forms into five main classes subdivided 
into twenty-six sub-fields. In order to obtain the classification of the building weathering damage, a set of questions was taken as a reference to perform the field assessments of about 200 façades distributed all over the Sassi of Matera site. Once the form was filled in for each façade of the surveyed buildings, we assessed the Decay Index (DI) considering the weights assigned to each of the chosen answers. Additionally, in order to appraise how the environmental and territorial conditions influenced the observed weathering, all the data were implemented in a spatial database to be handled with GIS spatial analysis techniques such as Map Algebra and Kernel Density Estimation. Finally, the significance of the obtained results in the site conservation management and the future research perspectives have been discussed.

\section{Introduction}

The knowledge of the current conservation state of historical centres as well as the analysis of the causes involved is essential for appropriate and suitable actions on which to found preventive countermeasures, especially for sites of outstanding value. The literature shows a number of contributions on the classification of weathering forms affecting the cultural heritage. De Gennaro et al. (2000) [1] performed a survey of the materials constituting the buildings of the Naples ancient city centre and their decay through a short description of the phenomena according to the NORMAL 1/88 standard [2]. In this way, a semi-quantitative assessment of the decay was carried out. The same method was also adopted by Carta et al. (2005) [3] for the historical centre of Sassari (Sardinia, Italy). In order to obtain digital thematic maps of the decay the data were implemented in a relational database.

Fitzner \& Heinrichs (2002) [4] and Fitzner et al. (2002, 2003) [5,6] introduced an important contribution to damage diagnosis on stone monuments applicable objectively and reproducibly to all stone types and all kinds of stone monuments. They present a monument mapping method that establishes a non-destructive procedure for in situ studies on stone damage. The authors carried out the assessment of the weathering typologies and their intensities based on the classification scheme taking into consideration four main levels of decay, each of them subdivided into sublevels. For example, level one was subdivided into four groups such as loss of stone material, discoloration/deposits, detachment of stone material, and fissures/deformation. In their turn, each of these groups was subdivided into other sub-categories. Following this classification scheme, the authors inventoried and mapped all the degradation typologies observed.

Fitzner \& Heinrichs (2002) [4] also classified the degree of weathering through a decay index. As a matter of fact, the authors proposed a Linear damage index and a Progressive damage index based on the intensity and the spatial distribution of weathering forms. The indices were assessed for numerous monuments around the world (Egypt, Jordan, Brazil, Germany).

Thornbush (2012) [7] created a classification system of weathering forms for the street of Queen's Lane in Oxford, where buildings are made up of limestone. The method used takes advantage of a high-resolution digital image photographic survey that allows the identification of the visible weathering forms classified by using the Size-Extent (S-E) index.

Through both fieldwork and laboratory analyses Calia et al. (2014) [8] built a database of the decay forms of the Pietra Gentile Stone monuments and minor buildings located in the Apulia Region (Southern Italy), according to the recommendations of the UNI 11182 (2006) standard [9]. 
As regards the analysis of possible cause-effect relationship, some authors considered the microclimate conditions in correlation with the degradation observed on the building façades. Especially since the eighties, much attention was devoted to the role played by the presence/absence of incident solar radiation on cultural stone surfaces. These studies showed that weathering prefers sun-facing and sun-shaded exposures. In particular, the decay observed in the most intense and longest sun-facing exposure was attributed to the material thermal stress; conversely, the weathering observed on shaded exposures, such as the biological colonization, was ascribed to the low water evaporation (for a literature review about the insolation effect, see Pope et al. (2002) [10]).

Some authors also investigated the influence of solar radiation and/or wind on stone weathering.

Dolske (1995) [11] examined the pressure of the environmental conditions such as relative humidity, air temperature, wind speed and solar radiation on the material weathering, with special attention to the actions exerted by the atmospheric pollutants. So as to relate the surface wetting with the presence of definite decay forms, Camuffo et al. (1999) [12] and Camuffo \& Sturaro (2001) [13], considering the effects of the local climate-urban environment interactions on the Pisa leaning tower or some Rome monuments, examined the façade exposure with respect to the wind-driven rain. Török (2003) [14] correlated the mineralogical features of the crusts identified on the buildings of Budapest with the exposure of the façades with respect to the combined rain/wind actions. Ponziani et al. (2012) [15] analysed the influence of the wall exposures to the insolation or winds on the weathering taking into account the degradation forms observed in the arch of Augustus in Aosta (Northern Italy).

Bearing this overview in mind, the authors planned a site-specific questionnaire to evaluate the conservation state and the Decay Index (DI) after on-field surveys over the Sassi of Matera site. Furthermore, in order to analyse the cause-effect relationship between the building stone decay and the site microclimate conditions, such as insolation and wind, the article proposes the use of GIS advanced spatial analysis techniques with particular reference to Map Algebra and Kernel Density, considered here for the first time within the context of the stone weathering investigation. Although some authors had already considered GIS to investigate stone degradation, their aim was mainly to survey, identify, classify and map the decay typologies observed on cultural stones by using and analysing historical or current imageries $[16,17,18]$, without bringing into play the advanced techniques that consider objects by using their geographical properties.

\section{The Sassi of Matera site}

The Sassi of Matera UNESCO site (The Sassi and the Park of the Rupestrian Churches of Matera; N $40^{\circ} 39^{\prime}$ 59', E $16^{\circ} 36^{\prime} 37^{\prime \prime}$ ') is inscribed on the World Heritage List since 1993 according to the III, IV and V UNESCO criteria (http://whc.unesco.org/en/list/670, accessed 22 November 2014).

Matera is a town located at an altitude of $401 \mathrm{~m}$ above the sea level in the eastern sector of the Basilicata region, in Southern Italy. The town is localized in the part of the Basilicata region that falls in the Cs Köppen-Geiger climate classification characterized by a warm temperate climate with dry summers [19].

The yearly mean of minimum and maximum temperatures are $10.4^{\circ} \mathrm{C}$ and $19.5^{\circ} \mathrm{C}$ respectively, with the highest summer temperature range reaching $12.0^{\circ} \mathrm{C}$ 
(http://clisun.casaccia.enea.it/, accessed on 24 March 2014). As concerns the precipitation, the yearly average is $543 \mathrm{~mm} /$ year [20].

From an urban-historical point of view, the most important sector of Matera is the Sassi site, the most ancient part of the town surrounded by the Gravina stream flowing along the deep natural gorge that strongly marks out the local landscape (Fig. 1). The Sassi represents an extraordinary settlement system which has recorded the spatial and temporal stratifications of the inhabitants' way of life uninterruptedly over more than two millennia. With the nearby Natural Archaeological Park of the Rupestrian Churches, the Sassi quarters have been defined by ICOMOS [21] as a "rock-cut settlement, architectural ensemble and landscape illustrating a number of significant stages in human history".

The whole area comprises about 80 small rock villages, the so-called casali. They have been inhabited in different historical phases as evidenced by the presence of caves that, in different periods, have been used as dwellings, churches, hermits' cells, craftman's workshops or stables. Due to the lack of urbanization in this area, the original shape of these villages is still legible. On the contrary, the two rock settlements developed around the Civita (the most anciently inhabited area) have been transformed, enlarged and incorporated into the urban tissue (the future Sassi quarters) (Fig.1).

Nowadays the Sassi represents an extraordinary example of a rich historical stratigraphy. As a matter of fact, stable settlements have been documented in an important way and uninterruptedly on top of Civita since the II millennium BC [22] and have grown along the right side of the Gravina stream whereon are still lying the two Sassi: the Caveoso and the Barisano. Significant findings from different periods have also been found since the late Bronze Age both in the historical Piano quarter and in the Sassi itself [23]. Many are the documents dating back to the 13th and 14th centuries which report the name Sasso that indicates a quarter carved out of the cliff [23].

The quarter called Piano is placed at the highest level of the Sassi, and it developed in the 18th century with bourgeois houses, not fully carved out of the rock but built, with large windows and more comfortable. On the contrary, the historical and oldest Sassi quarters were built in a vertical succession of excavated and/or constructed spaces, whose number varies according to the shape, nature and height of the calcarenite, locally known as tufo. The number of settlement levels range from three (in the Sasso Caveoso) to nine (Civita).

Between the early 50s and 70s a large mobilization, first cultural then political and legislative, has sought to heal the hard living conditions of the inhabitants hosted in the Sassi: unhealthy conditions and the spread of endemic diseases, overcrowding, sharing spaces with animals and a high infant mortality were just some of the most important problems. Furthermore, it was necessary to solve structural instability problems affecting both some buildings and streets, respectively involved in collapses or soil sinking [24]. To cope with these problems several laws were promulgated (Laws n. 619/1952, 299/1958, 126/1967, 1043/1971) to relocate the inhabitants: urban planners and sociologists designed new residential districts and rural villages.

Due to a long period of maintenance lacking, the seventies saw new building collapses. This forced the local government to announce the International Competition for the recovery of the Sassi: between 1974 and 1977 that institution fixed the guidelines to be ratified in the following years. The Competition put emphasis on three main topics: the current urban context and the development trend, the relationship between the Sassi historical centre and other areas of the Matera town, 
the regulatory and managerial plans [25]. In the second half of the 80s, law n. 771/86 allocated 100 billion of Italian lire (about 52 million Euros without taking the inflation rate into account) for the conservation and the recovery of the historic quarters. The actions were arranged through two biennial plans: the first involved the Sasso Barisano, the second the Sasso Caveoso. The programs regarded the interventions in the urban fabric as well as the rebuilding of infrastructure network [26]. The challenge was not easy to be met both because of the site topography and the structure of the settlement. Regarding this subject, the scientific community has discussed in depth the Sassi forma urbis and the digging out techniques used over the centuries. As a matter of fact different typologies of housings can be identified: the cave, living archetype; the lamione, a single room with a vaulted roof, and the palaziate houses, built with the material dug from inside the cave. Initially the debris materials were used only to reduce the cave opening. As time went by, a new architectural module replaced the cave, the so-called lamione, most likely introduced by non-local workers [27]. Afterwards, a top floor started to be built: in this way the palaziate houses were born and, in particular, the Vicinato, a courtyard around which groups of houses clustered throughout the site. In these public spaces the Sassi inhabitants carried out daily rituals of work and socialization.

However, it is worth taking into account that a national and international debate on the conservation of the Sassi started simultaneously with the knowledge of them. In point of fact, the codes of good practice for the safety and recovery of the Sassi were published. Those codes focused essentially on two main aspects: the analyses of the traditional (local) building techniques and the proposals of housing plans to recover the decayed architectural heritage [28,29].

The hints included in the handbooks were put into practice starting from 1996, when the first step of the recovery planned by law n. 771/86 was made: the areas closer to the major driveway roads (more attractive for private investment) were preferred so as triggering a "virtuous circle of development" [30]. The recovery actions tried to preserve the original building materials avoiding destructions or replacements of historical building elements. The inspiring principle was mainly to reduce the intrusive or pervasive interventions considering the environmental, historical and archaeological peculiarities of the site, but also bearing in mind the aspects of social and economic growth [30]. However, the recovery plan has also been strongly criticized as considered inadequate and contradictory. The merchandising of the heritage, which was the aim of the recovery, has come in for a lot of criticism because the heritage has been converted to adapt itself to today's market demands and today's life style, although the heritage has been well preserved [31].

When it comes to cultural tourism, the law-inspired biennial plans seem to have revitalized the area so as to increase tourism significantly [30]. Actually, the arrivals of Italian and foreign tourists in the time span between 1999 and 2011 increased by $198 \%$ and $423 \%$ respectively [32]. However, two aspects need to be emphasized. The first regards the fact that some recommendations from ICOMOS were necessary to guarantee a sustainable tourism able to enhance the economy of the area without damaging the local heritage [33]. The second concerns the fact that tourism seems more focused on the attraction itself (Sassi) than on the different components of a complete tourism experience in the Sassi quarters [32].

The Sassi site was included in the UNESCO World Heritage List in 1993 and designated as 2019 European Capital of Culture in October 2014. These prestigious international acknowledgements impose an obligation and further efforts to be made by the stakeholders to assure mitigation measures aimed at reducing the factors 
influencing the posterity of such a valuable site. This requires an evaluation both of the settlement conservation state and the influence of environmental variables on it. With this purpose, we started a site survey to analyze the conservation state of the monuments and the buildings of the Sassi of Matera. In addition, the surveyed data were correlated with some environmental features to determine the possible factors controlling the stone decay process.

\section{Methodologies}

\subsection{The Calcarenite of Gravina}

According to the aim of this study, we started the survey of decay forms affecting the monuments and buildings hosted in the Sassi site. These are made up of a typical stone locally known as Tufo calcareo (Calcareous Tuff). This is dug out of the Calcarenite of Gravina formation (Early Pleistocene-Piacenzian), that is the main lithology outcropping all over the area under investigation -also in the neighbouring Apulia region, and it lies unconformable on the "Calcare di Altamura" foreland formation (upper Cretaceous) [34].

The Calcarenite of Gravina consists of a yellowish white fossiliferous calcarenite, generally massive and scarcely compact having a variable grain size, for what it was classified into three typologies: fine-grained grainstone, medium-grained packstone, and coarse-grained grainstone [35].

The general fabric referred to grainstone as viewed in thin section through a polarizing optical microscope (Fig. 2) is made up by sub-rounded and rarely subangular bioclasts, rare lithoclasts with a self-supporting framework from poorly to moderately sorted. The bioclastic limestone is made up by the remains of benthonic foraminifera, bryozoans, bivalves, gastropods, echinoderms and calcareous algae. The bioclasts and lithoclasts are bimodal sized, 200 to 800 microns, and the micritic matrix is poor.

From a hydro-geological point of view the Matera Calcarenite does not show water table due both to low permeability from porosity and quite scarce presence of tectonic joints that makes the rock scarcely permeable. Furthermore an impermeable geological substratum is lacking [24].

As concerns the physical and mechanical features of Calcarenite, with a carbonate content ranging from $85.2 \%$ to $98.5 \%$, they are conditioned by highly variable degree of diagenesis of the rock that changes throughout the formation causing a cementation (mainly calcareous) that locally can be very scarce [24]. That variability implies quite wide range of the physical/mechanical features of the rock that are the following: unitweight $1.337-1.844 \mathrm{gr} / \mathrm{cm}^{3}$, dry density ranged from 1.36 to $1.51\left(\mathrm{t} / \mathrm{m}^{3}\right)$, specific gravity $2.696-2.708 \mathrm{gr} / \mathrm{cm}^{3}$, total porosity ranging from 44.0 to $49.5 \%$, pores ranging from 10 to 500 microns in width, cohesion $2.0-6.3 \mathrm{Kg} / \mathrm{cm}^{2}$, traction resistance 1.82$5.08 \mathrm{Kg} / \mathrm{cm}^{2}$ [24,35,36,37]. Furthermore, the Tufo shows poor mechanical features as indicated by the uniaxial compressive strength that shows average values from 2.20 to 2.34 MPa [37,38].

Despite these properties (high porosity, and therefore prone to absorb water, its carbonate composition and its low mechanical strength), due to its availability and easy workability, the calcarenite has been widely used over the centuries as a building material both in the Apulia and Basilicata regions.

\subsection{The questionnaire and the survey method}


The weathering damage affecting the calcarenite building material was classified through an ad hoc questionnaire that includes the specific alterations identified through the field assessments.

The survey form was arranged mainly taking advantage of the analysis of the UNI 11182 (2006) rule [9], ICOMOS-ISCS (2008) [39] and a wider literature review $[4,5,6,40]$. After that, we fixed the questionnaire entries by using the observation made by the preliminary on field investigations that allowed differentiating the individual degradations typical of the site.

In detail, the questionnaire includes five main categories: the presence of biological matter, the presence of deposits, the loss of material, the changing in colour of surface, and aesthetical decay. Each main category contains some sub-classes where specific decay typologies are included (Tab 1).

In particular, the Presence of biological matter consists of five specific stone degradations including the Biological colonization of micro and/or macro-organisms considered through visible growths of algae, fungi, lichens, moss (Fig. 3a), the Presence of vegetation related to individual herbaceous shrubby or arboreal (Fig 3b), the Biological Patina as thin and homogeneous patina, mainly consisting of microorganisms, varying in texture, colour and adhesion to the substrate and finally Bird dropping (Fig 3c) and Urine stains.

The "Presence of deposits" category includes: Superficial deposits as the accumulation of materials such as dust, deposits with little coherence and poor adhesion to the substrate, Efflorescences /sub-efflorescences as shallow formations of crystalline salts with powdery or filamentous appearance, usually whitish/light in colour; Incrustations as stratiform deposits commonly compact and adherent to the substrate (defined as concretions when the deposit develops preferentially in one direction and it does not coincide with the stone surface assuming stalactite or stalagmite forms), Crust related to the modification of the superficial layer of stone material with a variable thickness, usually attending to its texture and/or composition with respect to the underneath substrate.

The "Loss of material" main category includes the Alveolar weathering as the presence of cavities with a variable size and shape (so-called alveoli), often interconnected and with a non-uniform distribution (Fig.3d), Exfoliation i.e. the formation of one or more laminar portions (of reduced thickness and sub-parallel between them, known as flaking) (Fig.3e), Scaling as detachment of parts of irregular shape and consistent and non-uniform thickness (called scales, often related to the interruption of the original material), Erosion as the removal of material from the surface which, in most of the cases, is compact (Fig.3f), Differential decay as the loss of material from the surface which shows the heterogeneity of the texture and structure (Fig.3g), Disaggregation/pulverization, a de-cohesion with the fall of material in the shape of dust or very minute fragments (Fig.3h), Pitting as the formation of blind holes, numerous and closely spaced, with a hemispherical shape and a maximum diameter of a few millimetres, Fracturing or cracking (solution of continuity in the material that implies the reciprocal displacement of the parts) (Fig. 4a), and finally Rubbings/scratches due to an anthropogenic impact (Fig. 4b).

The "Changing in colour of surface" main category can be subdivided into four main sub-classes: Rising front of moisture that is the limit of the water migration, well evident through the formation of efflorescence and/or loss of material, usually accompanied by a change in the colour saturation in the underneath area due to the accumulation of water (Fig.4c); Staining, vertical and parallel to trace progress due to the casting of water mixed with dust and dirt; Stains, localized colour variation of the 
stone surface correlated with the presence of natural or other materials; Soiling, $a$ phenomenon generally related to the deposition of airborne particulate from natural sources as well as pollutants that can be recognized through the darkening of the surface that is the change in light reflectance (Fig.4d).

The "Aesthetical decay" is divided in two main classes. The first includes the Aesthetical decay reflecting the "addition" of human-made elements such as Wires/pipelines (Fig.4 e) and Grafitis/paintings, i.e. undesired affixing on the surface or paints (Fig. 3f). The second embraces the aesthetical decay due both to the Replacement of the original elements damaged with other similar blocks of stone (Fig. $4 \mathrm{~g}$ ) and the Refacing/repair with mortar or protective material to restore the original layout and/or strengthen the stone (Fig. 4h). However, both classes include actions engendering an unpleasant visual impact due to new elements that are inharmoniously integrated with the building layout.

Once fixed the weathering typologies to be included in the questionnaire, in order to assess the weathering of each façade quantitatively the Decay Index (DI) was introduced according to the following formula:

$$
D I=\frac{\sum_{i=1}^{n} X i * W i}{\sum_{i=1}^{n} W i}
$$

where $X i$ is the percentage of the area affected by a definite decay with respect to the overall area of the surface surveyed; $W i$ is the weight attributed to each specific decay form that represents the risk factor for the conservation. The maximum $W i$ attributed was 1.0 that represents the highest risk value; the lower $W i$ assigned was 0.5.

High weights related to weathering were attributed implying directly or indirectly a reduction in the volume and/or decay of the cultural stone physical-mechanical properties (e.g.: loss of material and presence of biological matter). An aspect considered important was also the phenomena particularly diffused over the monument surfaces and affecting the entire thickness of the stone walls (e.g.: rising front of moisture).For the decay having a low impact on the stone properties the weight was reduced accordingly (e.g.: presence of deposits "main category").

As regards $n$, it represents the total number of the decay damage surveyed on the building surface observed.

After having fixed the criteria to compute the DI, to assess the conservation state of the buildings hosted in the Sassi, we performed the extensive field survey based on visual analysis performed at micro- to mesoscale (from some $\mathrm{mm}$ to $\mathrm{m}$ ).

During the on field investigation we filled in the questionnaire for about 200 façades and for each of them one or more photos were taken and ortho-rectified so as to allow us to properly estimate the percentage of the area affected by each specific typology of weathering. The choice of the walls to be considered for the degradation analysis was made mainly looking at the accessibility of the surfaces and the significance of the alteration encountered.

The field assessment started $1^{\text {st }}$ July 2013 and took one week and two persons, while about two months were needed for the processing of the digital imageries and the assessment of the $D I$ for all the surfaces considered.

All the data deriving both from the survey and the computation, were included in a GIS to make it possible to evaluate the influence of the local environmental 
conditions on the development of the decay by using two techniques of spatial analysis: Map algebra and Kernel Density Estimation.

\subsection{The spatial analysis}

\subsubsection{Map algebra}

Map algebra is a high-level language for spatial modelling that allows developing complex spatial models by using the raster format [41]. Three main analysis groups exist [42]: 1) the local functions allow calculating, from one or more input rasters, operations applied to the corresponding pixel of each input raster; 2) the focal functions allow calculating expressions applied on the pixel itself of the input raster and on a previously defined neighbourhood; 3) the zonal functions allow calculating the algebra expression inside the zones defined by a raster.

By combining these functions it is possible to obtain many other types of analysis, such as surface analysis to investigate and classify landscape and terrain.

Hillshade is a technique of surface analysis that allows obtaining, for each pixel of the output raster, the illumination of a building surface. Values of pixel in the output raster vary from 0 (minimum illumination) to 255 (maximum illumination). The main parameters taken into account in the hillshade analysis are the azimuth and altitude of the sun above the horizon.

\subsubsection{Kernel Density Estimation (KDE)}

KDE is a technique of point spatial analysis that shows how the expected value (mean) of a spatial event varies in the space.

KDE is a moving three-dimensional function, weighing events within their influence sphere according to their distance from the point at which the intensity is being estimated [43]. In each spatial point KDE is defined as (Eq.1):

$$
\text { (1) } \lambda(L)=\sum_{i=1}^{n} \frac{1}{\tau^{2}} k\left(\frac{L-L_{i}}{\tau}\right)
$$

where $\lambda$ is the distribution intensity of points, $L_{i}$ is the event $i, k$ is the kernel function and $\tau$ is the bandwidth. The main factor influencing density values is the bandwidth: if $\tau$ is too high the value of $\lambda$ is closer to simple density; if $\tau$ is too low the surface does not capture the phenomenon. In many cases a distance measurement, called Nearest Neighbour Observed Distance (NNOD), is used as bandwidth. It is expressed by (Eq. 2):

$$
\text { (2) } N N O D=\frac{\sum_{i=1}^{n} d_{\min }\left(s_{i}, s_{j}\right)}{n}
$$

where $d_{\min }(S i, S j)$ is the distance between each point and its nearest neighbour, and $n$ is the number of points in the distribution.

For a deeper review of KDE and its parameters and use in combination with NNOD see [44].

\section{Results and discussion}

\subsection{The weathering damage of some monuments}

The investigation of the Sassi monuments has shown a wide range of stone breaking down that can be resumed in three significant examples, the Cathedral, St. Domenico and St. Francesco churches (Tab. 1). The DI average value for each of the monuments is $10.00,6.45$, and 9.70 , respectively. 
As regards the Cathedral we investigated the main façade facing west, and two side walls facing north and south (Tab. 1 and Fig. 5). In detail, the DI for the walls facing west and north assume comparable values (8.5 and 8.1, respectively). Conversely, the side facing south shows the highest $D I$ value (13.4).

Examining the question from close up, it emerges that the extension of the different typologies of degradation changes in accordance with the exposure of the façades. For example, the biological colonization appears to be well developed on the north façade and reduces progressively from north to south passing through west. The loss of material is limited on the main façade facing west; other erosion variety are very clear only on the west and north façades. As regards the changing in colour, we found very high values for all the three façades. In particular, this phenomenon is plainly evident in the west and south façades where it reaches as much as $40 \%$ of the total surface, while on the surface facing north the value is the lowest. Also the soiling phenomenon appears clearly in all the three façades, especially in those facing west and south.

As concerns the St. Domenico church we performed the survey of two surfaces, the west-oriented main façade and the south-oriented lateral wall. The estimated DI values are 4.2 and 8.7, respectively. Details on the weathering typologies are given in Tab. 1 and Fig. 5. From them we can observe that on the one hand the data show that the Presence of biological matter is limited on the south; on the other hand the loss of materials concerns both the façades, but a prevalence of alveolar weathering or differential decay prevails on the surface facing south.

As regards the St. Francesco d'Assisi church we investigated only the main front facing SSW, for which the $D I$ is equal to 9.7. This value can be explained mainly by the important Rising front of moisture and the significance of soiling (Tab. 1 and Fig. 5). Also the Loss of materials represented by both the Alveolar weathering and Erosion contributed to the rise of the DI value.

Summarizing, the analysis comes into sight that the number of decays and their typology and size on the wall surface change to a great extent from one surface to another and the interaction between two or more decays is quite evident.

\subsection{The Decay Index over the investigated area}

This section analyses the relationship between the weathering and the exposure of the façades to wind and /or solar irradiance. All this allowed getting some clues about the environmental variables that can be involved in controlling the decay.

As said before, the site study was carried out on about 200 façades of the buildings. The statistical analysis shows that the height of the façades is about 5 meters and their area about 36 square meters, on average. Details about the dimensional aspect are shown in Fig. 6.

For each of the 200 façades we estimated the $D I$ that takes values ranging from 1.2 to 13.7, with an average of 5.8 (Tab. 2). Analysing the DI distinctly for each class, we can notice that most (44.3\%) of the surfaces falls in Class 2 having a low-medium DI (from 3.7 to 6.2) and the classes representing higher indexes include a number of surfaces that decreases as the DI increases (class 3 represents $28.4 \%$, class 4 embraces $7.1 \%$ and class 5 is made of $2.7 \%$ out of the total number of the façades).

With the purpose of showing how the decay index changes over the territory and what areas are characterized by hot and cold spot of decay (that are areas with groups of elements with a high or low level of decay, respectively) the data were represented on the site map through the KDE, once the DI was assessed for each façade, which requested to compute the NNOD value, found equal to $14 \mathrm{~m}$. This number was used as the bandwidth in KD estimation. The resulting raster was classified in quantile 
intervals, in order to have classes with equal frequency density. Moreover, in order to analyse the influence of two environmental variables on decay, we also performed the correlation between the DI value for each façade and its exposure both to the predominant wind directions and sunlight.

The wind data were made available by Alsia (Agenzia Lucana di Sviluppo e di Innovazione in Agricoltura - Regione Basilicata, http://www.ssabasilicata.it/, accessed on 21 March 2014) from Matera weather station. As concerns the solar radiation it was not considered directly but by calculating hillshade on the walls. Furthermore, the height of the sun over the horizon was gained taking advantage from on-line tool resources (http://www.sunearthtools.com/dp/tools/pos_sun.php?lang=it, accessed on 28 January 2014).

KDE is used in this work, with results obtained in Fig.7, to highlight hotspot of decay index, in order to compare this with wind exposure data. This is done in the following way: KDE takes the index associated to each wall (values corresponding to the wall line) and transform this information in decay density distributed around the walls, that helps to understand visually and numerically the correspondence with wind exposure data.

As regards the spatial pattern of DI, Fig. 7 shows that hot spots are very clear especially in the north and south area. Conversely, cold spots can be found to the south-east of the area under investigation.

Considering now the influence of the wind on DI, for each wall the number of exposure days was calculated by considering the time-window of two years, from $1^{\text {st }}$ January 2012 to $31^{\text {st }}$ December 2013. Therefore, that period was used as a sample in analysing the average exposure of the building walls to the wind.

The exposure data indicate that the prevailing wind directions were N-NE (from 160 to 270 days of frequency out of 2 years). Furthermore, the wind assumed a high intensity during the winter months, while from the NW, W, and SW directions they were less frequent (from 60 to 100 days of frequency out of 2 years). Finally, the winds from southern, southern-eastern and eastern directions had scarce importance ( $<50$ days of frequency over the two years of observations).

With all this in mind, the winds having direction included between $\pm 67.5^{\circ}$ as to the wall exposure were assigned to each wall. The number of wind exposure days was compared with the DI-based KDE results over the whole area of the Sassi thus obtaining a good correlation between the data (Fig. 7). As a matter of fact, analysing especially the north and south area of the Sassi, where hot spots are present, we can argue that as the number of wind-exposure days (thickness of the black segments in Fig. 7) increases the $D I$ value rises on average, thus suggesting a certain influence of the wind on the weathering actions. The uncorrelated data can be due to the circumstance that, as we will see below, more than one environmental factor acts in causing the observed decay and also the site urban conditions can influence the action of external factors (e.g.: buildings close to each other).

For what concerns the exposure to sunlight, one of the other main factors that can influence the material decay due to the thermal stress, the hill shade analysis was performed by considering the altitude and the azimuth of the sun both in summer and winter solstice in view of the time interval wide one hour. Table 2a shows the relationship between the sun exposure in summer, ranging from 0 (façades in shadow) to 255 (the brightest façades), and DI. In detail, the façade exposure was sub-divided into five classes where class 1 includes surfaces having the lowest incoming solar radiation and class 5 the highest. The same approach was followed for the DIs grouped into five classes, the last of which reflects the highest decay. 
Analyzing the data, it can be noticed that most of the façades ( 76\%) belongs to the fifth class that fits with the highest excursion of illumination (range of exposure to the sun). Furthermore, the number of surfaces, taken on the whole, increases proportionally with the augment of the excursion range. In point of fact, there is only $1 \%$ in class 1 (sun exposure 0-51), 1.6\% in class 2 (52-102), 9.2\% in class 3 (103153), and $14.8 \%$ in class 4 (154-204). To go through the data with a fine-tooth comb, it can be argued that taking into account only 70 façades with a medium-high $D I$, from Class 3 onwards (the rows in grey colour in Tab. 2a), 62 of them ( 88\%) are included in the high or the highest range of exposure to the sun (Classes 4 or 5) so putting into evidence that the solar irradiance plays a possible role in controlling the weathering. This is indirectly confirmed by the independent analysis of the statistical distribution of most sunny façades against wind exposure. As a matter of fact, taking into account the 43 walls falling into the insulation class 5 , the most significant group statistically speaking, one can make out that most of the façades is exposed to the lower wind classes 1 or 2 that reflect scanty or little importance of the wind actions (the row in grey colour in Tab. 2b). This circumstance seems indirectly to confirm the role of the solar irradiance in determining the decay during at least the summer.

Looking at the winter solstice, it emerges that numerous walls that were subject to the high sun irradiance in summer are parcelled out into classes representing lower incoming solar radiation (Tab. 3a). This is due to the azimuth $\left(120^{\circ}-239^{\circ}\right.$ in winter against $57^{\circ}-302^{\circ}$ in summer) and sun altitude in winter. These astronomical circumstances determine that a portion of the surfaces exposed in class 5 in summer are back out of the maximum excursion in winter and some of the façades prone to the high irradiance in summer are exposed to the low incoming solar radiation in winter (classes 1 and 2) just when the highest wind actions are expected on the same surfaces. As a matter of fact, if we analyse all the façades having DI equal to 3 (row in grey in Tab. 3a), the most significant class, statistically speaking, among those with higher DI, one can see that the walls having sun exposure from class 3 onwards (c,d,e) are little subject to the wind exposure (wind classes 1 and 2 of Tab. 3b). Conversely, the classes reflecting a sun exposure of class 1 or 2 (a,b in Tab. 3a) are affected by the heavier wind actions (wind classes 3 and 4 of Tab. 3b).

From this analysis emerges that the weathering of most of the surfaces having $D I$ greater than or equal to 3 seems to be guided by the high irradiance rate in summer, the season in which the daily air temperature excursion is the highest. Some of these façades are also exposed to the cold wind blowing from the north sectors in winter, putting into evidence a possible twofold action of the two environmental features. Summarizing, the results are in accordance with what other authors observed in other monumental and environmental contexts [16]. In point of fact, the weathering on the surfaces exposed to the south seems to be mainly guided from the thermal stress and thermal cycles enhanced by the direct solar radiation.

As concern the surfaces exposed to the north, where we observe mainly biological colonization, the decay is probably due to the high presence of water caused by the shaded exposure that implies low rate of water evaporation. In addition, the winddriven rain is also another factor that probably exerts a noteworthy action. As a matter of fact, the role that precipitation plays is powerfully dependent on the direction from which the wind blows during the meteorological event due to the circumstance that the wind transports the suspended raindrops towards the surfaces [45].Taking that in mind and analysing the wind rose during the raining days in Matera (Fig. 8), we can note that the surfaces exposed to wetting are mainly those facing the north. Therefore, through 
the exposed surfaces, the highly-porous calcarenite will increase the water content becoming a suitable habitat for the biological colonization.

\section{Conclusions}

This paper has dealt with the analysis of the conservation state of the Sassi of Matera, a site of outstanding universal value.

Two aspects have been addressed here: the analysis of the decay through a specific index and the investigation, at a territorial scale, on how the environmental factors condition the conservation state.

To reach these aims, we drew up a questionnaire on the basis of the features of the area investigated. Through the on-site surveys, the questionnaire was filled in for about 200 façades, putting into evidence that the Sassi site has a medium-low decay index, on average.

The research has also analysed the influence of two main environmental parameters on the weathering. In order to do that we set a methodology that explored the relationship between the decay, on the one hand, and the sun exposure and the wind flow, on the other. The approach followed is based on the application of Map Algebra and Kernel Density Estimation spatial analysis techniques whose results fit quite well with what might be expected. As a matter of fact, the surfaces facing north seem to be most influenced by the wind/rain actions; on the contrary, the decay of the walls facing south seems to be guided mainly by the sun exposure.

From a methodological point of view, considering the encouraging results on the novel approach based on the use of the spatial analysis techniques, further researches will consider a higher number of environmental/territorial/urban factors conditioning the decay such as the pollution, the mutual influence of the buildings, the width of streets and so on. All that will allow evaluating a tentative protocol to be followed in different environmental and cultural heritage contexts all over the world to gain evidence about the cause-effect relationship of the different weathering forms observed.

Concluding, from a wide-ranging perspective it emerges that this research can be a valuable tool to provide a fitting method both to analyse and update the data regarding the state of conservation of historical centre and plan conservation strategies that policymakers will have to put into the field. For example, the output of this research can help the institutions in scheduling the restoration actions over the time identifying the buildings/façades that should be restored with main aim of allocating adequate financial resources in good time.

\section{ACKNOWLEDGEMENTS}

The authors thank the Basilicata Region for supporting this activity in the framework of the Project "PRO_CULT" (Advanced methodological approaches and technologies for Protection and Security of Cultural Heritage) financed by Regional Operational Programme ERDF 2007/2013. Furthermore, the authors wish to thank three anonymous reviewers for taking the time to provide detailed and constructive comments that greatly improved the article.

\section{REFERENCES}

[1] M. De Gennaro, D. Calcaterra, P. Cappelletti, A. Langella, V. Morra, Building stone and related weathering in the architecture of the ancient city of Naples, Journal of Cultural Heritage 1 (2000) 399414.

[2] Raccomandazione NORMAL 1/88 - Alterazioni macroscopiche dei materiali lapidei: lessico. CNRICR, Roma, (1990) [in Italian]. 
[3] L. Carta, D.Calcaterra, P. Cappelletti, A. Langella, \& M. De’ Gennaro, The stone materials in the historic architecture of the ancient center of Sassari: distribution and state of conservation, Journal of Cultural Heritage, 6 (2005) 277-286.

[4] B. Fitzner, K. Heinrichs, Damage diagnosis on stone monuments weathering forms, damage categories and damage indices. In: Prikryl R, Viles HA, editors. Understanding and managing stone decay. Prague: The Karolinum Press, (2002) 11-56.

[5] B. Fitzner, K. Heinrichs \& D. La Bouchardiere, Damage index for stone monuments.- in: Galan, E. \& Zezza, F. (ed.): Protection and Conservation of the Cultural Heritage of the Mediterranean Cities, Proceedings of the 5th International Symposium on the Conservation of Monuments in the Mediterranean Basin, Sevilla, Spain, 5-8 April 2000, (2002) 315-326.

[6] B. Fitzner, K. Heinrichs,D. La Bouchardiere, Weathering damage on Pharaonic sandstone monuments in Luxor-Egypt, Building and Environment 38 (2003) 1089-1103.

[7] M.J. Thornbush, A Site-Specific Index Based on Weathering Forms Visibile in Central Oxford, UK, Geosciences (2012), 2, 277-297.

[8] A. Calia, M. Sileo, L. Matera, Provenance, characterization and decay of a porous calcarenite of the Puglia region ("Pietra Gentile"). London, Special Publication "Stone in Historic Buildings: Characterization and Performance", (2014) 4, 47-70. DOI: 10.1144/SP391.11.

[9] UNI11182, Beni culturali. Materiali lapidei naturali ed artificiali. Descrizione della forma di alterazione, Termini e definizioni, (2006) [in Italian].

[10] G.A. Pope, T.C. Meierding, T.R. Paradise, Geomorphology's role in the study of weathering of cultural stone, Geomorphology 47 (2002) 211-225.

[11] D. Dolske, Deposition of atmospheric pollutants to monuments, statues, and buildings, The Science of Total Environment, 167, (1995) 15-31.

[12] D. Camuffo, G. Sturaro and A. Valentino, Urban Climatology Applied to thr Deterioration of the Pisa Leaning Tower, Italy, Theor. Climatol. 63, (1999) 223-231.

[13] D. Camuffo, G. Sturaro, The climate of Rome and its action on monument decay, Climate Research, 16, (2001) 145-155.

[14] A. Török, Surface strenght and mineralogy of weathering crusts on limestone buildings in Budapest, Building and Environment 38 (2003), 1185-1192.

[15] D. Ponziani E. Ferrero, L. Apollonia, S. Migliorini, Effects of temperature and humidity excursions and wind exposure on the arch of Augustus in Aosta, Journal of Cultural Heritage 13 (2012) 462-468.

[16] R. Inkpen, B. Duane, J. Burdett, T. Yates, Assessing stone degradation using an integrated database and geographical information system (GIS), Environ. Geol. 56 (2008) 789-801.

[17] M.F. André, F. Vautier, O. Voldoire , E. Roussel, Accelerated stone deterioration induced by forest clearance around the Angkor temples. Science of the Total Environment, Vol. 493, 15 September 2014, (2014) 98-108. doi:10.1016/j.scitotenv.2014.05.141.

[18] M. Gomez-Heras, L. Lopez-Gonzalez, S. García-Morales, R. Fort, M. Alvarez de Buergo, Integrating non-destructive techniques with photogrammetry 3D models. In Rogerio-Candeleda MA (Ed) Science, Technology and Cultural Heritage, CRC Press/Balkema, Leiden. (2014), 429-434. ISBN: 978-1-138-02744-2.

[19] M. Kottek,. J. Grieser, C. Beck, B.Rudolf, and F. Rubel, 2006: World Map of the Köppen-Geiger climate classification updated. Meteorol. Z., 15, 259-263. DOI: 10.1127/0941-2948/2006/0130.

[20] A. De Stefano, M. Lorusso, L'analisi dei dati pluviometrici in Basilicata. In "Cultura, Il Territorio". Regione Basilicata (2002) 8p, [in Italian].

[21] ICOMOS, http://whc.unesco.org/archive/advisory_body_evaluation/670 - WORLD HERITAGE LIST Matera No 670( 1993).

[22] M. Cipolloni Sampò, L'Eneolitico e l'Età del Bronzo, In: Cestaro A. and De Rosa G. (eds), Storia della Basilicata. Adamesteanu D (ed) L'Antichità. Laterza (1999): 67-136, [in Italian].

[23] C.D. Fonseca, Il popolamento rupestre, In: De Rosa G. and Cestaro A. (eds), Storia della Basilicata. Fonseca C.D. (ed) Il Medioevo, Laterza (2006), 164-173, [in Italian].

[24] V, Cotecchia, D. Grassi, Stato di conservazione dei "Sassi” di Matera (Basilicata) in rapporto alle condizioni geomorfologiche e geomeccaniche del territorio e alle azioni antropiche. Geol. Appl. e Idrogeol. (1975) 10 (1), 55-105, [in Italian].

[25] Comune di Matera, Concorso Internazionale per il restauro urbanistico ambientale dei rioni Sassi, Stampa delle arti grafiche BMG Matera (1978), [in Italian].

[26] G.De Mare \& B.Ferrara, Reinfrastrutturazione del Rione Sassi a Matera. Misura degli effetti sulla propensione dei privati alla riqualificazione del patrimonio edilizio. In AA.VV. La selezione dei progetti e il controllo dei costi nella riqualificazione urbana e territoriale, Firenze, Alinea. (2004), 269282 ISBN:8881258374, [in Italian]. 
[27] P. Laureano, Giardini di pietra, I Sassi di Matera e la civiltà mediterranea ed. Bollati Boringhieri, Collana Gli Archi, (2002) ISBN: 8833914011, [in Italian].

[28] A. Giuffrè, "Codice di pratica per la sicurezza e la conservazione dei Sassi di Matera" - Collana Zetema. Ed. La Bautta (1992), [in Italian].

[29] Comune di Matera, Archivio Ufficio Sassi, Documento n.4: Concessioni e Manuale del Recupero, Matera Ottobre (1987), [in Italian].

[30] M. Valente, Evoluzione socio-economica dei Sassi di Matera nel XX sec. Consiglio regionale della Basilicata, (2007) 119-138 [in Italian].

[31] D. Rodwell, Materan contradictions: architecture, preservation and politics, by Anne Parmly Toxey, Ashgate 2011. Journal of Architectural Conservation, (2014) 20 (1) 68-69.

[32] P. Buonincontri, G.Maggiore, La tourism experience come leva critica per il marketing delle destinazioni: il caso dei Sassi di Matera in Atti del IX convegno annuale della Società Italiana Marketing dal titolo «Marketing Internazionale ed Effetto Country of Origin». Benevento, 20 e 21 Settembre 2012, (2012) 1-19. ISBN: 9788890766206.

[33] P. Buonincontri, M.I. Simeon, Cultural tourism in world heritage sites: an empirical study on an italian marginal area. In 5th Annual EuroMed Conference of the EuroMed Academy of business, (2012) 226-239.

[34] N.Ciaranfi, M.Maggiore, P. Pieri, L. Rapisardi, G. Richetti \& N. Walsh, Considerazioni sulla neotettonica della Fossa bradanica, In :Contributi Preliminari alla Realizzazione della Carta Neotettonica d'Italia, Pubbl. nº 251 del Prog. Fin. Geodinamica, (1979) 73-95, [in Italian].

[35] G.F. Andriani \& N. Walsh, Fabric, porosity and water permeability of calcarenites from Apulia SE Italy) used as building and ornamental stone. Bull.Eng. Geol. Env., 62 (2003) 77-84.

[36] M. Sileo, Individuazione e caratterizzazione geologica, chimico-mineralogica e petrofisica di calcareniti tenere della Puglia e della Basilicata in relazione alle problematiche di provenienza e conservazione dei Beni Culturali. PhD thesis (2012), Basilicata University - IBAM (Institute of Archaeological and Monumental Heritage), CNR (Italy), [in Italian].

[37] G.F.Andriani \& N. Walsh, The effects of wetting and drying, and marine salt crystallization on calcarenite rocks used as building material in historic monuments. In: Prikryl R. \& Smith B. J. eds) Building Stone decay: From Diagnosis to Conservation. Geological Society, London, Special Publications, v. 271 (2007) 179-188.

[38] B. Radina \& N. Walsh, - Proprietà tecniche delle calcareniti (Tufi Calcarei) di Gravina in Puglia. Geol. Appl. e Idrog (1972) 53-73, [in Italian].

[39] ICOMOS-ISCS, Illustrated glossary on stone deterioration patterns. 78 p. (Monuments and Sites; XV). ISBN: 978-2-918086-00-0.

[40] H.A Viles, A.A. Gorbushina, Soiling and microbial colonisation on urban roadside limestone: a three year study in Oxford, England, Building and Environment, 38 (2003) 1217-1224.

[41] M.N. De Mers, GIS Modeling in raster, Wiley \& Sons, USA (2002).

[42] C.D. Tomlin, Geographic Information Systems and Cartographic Modeling. Englewood Cliffs, New Jersey: Prentice Hall, (1990).

[43] A.C. Gatrell, T.C. Bailey, P.J. Diggle, B.S. Rowlingson, Spatial Point Pattern Analysis and Its Application in Geographical Epidemiology, Transaction of Institute of British Geographer, 21 (1996) 256-271.

[44] M.Danese, M. Lazzari, B. Murgante, Kernel Density Estimation Methods for a Geostatistical Approach in Seismic Risk Analysis: the Case Study of Potenza Hilltop Town (southern Italy). In: Gervasi O., Murgante B.,. Laganà A, Taniar D., Mun Y., Gavrilova M., (eds.) (ICCSA 2008) Lecture Notes in Computer Science vol. 5072(2008), 415-427. Springer-Verlag, Berlin. ISSN: 0302-9743.

[45] D. Camuffo, G. Sturaro, A. Valentino, The Climate of Venice and its Action on Monument Decay, Proceedings of the 4th International Symposium on the Conservation of Monuments in the Mediterranean, Vol. 2 (1997) 53-65. 


\begin{tabular}{|c|c|c|c|c|c|c|c|c|c|}
\hline \multirow[b]{2}{*}{ MAIN CATEGORY } & \multirow{2}{*}{\multicolumn{2}{|c|}{ SPECIFIC DECAY FORM }} & \multirow[b]{2}{*}{ Wi } & $\mathrm{X} 1$ & $\mathrm{X} 2$ & X3 & $\mathrm{X} 4$ & $\mathrm{X} 5$ & $\mathrm{X} 6$ \\
\hline & & & & 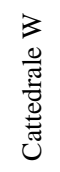 & 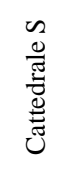 & 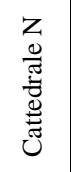 & 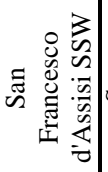 & के & 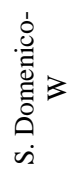 \\
\hline \multirow{5}{*}{$\begin{array}{l}\text { Presence of biological } \\
\text { matter }\end{array}$} & & Biological colonization & 0.8 & 2.8 & 1.4 & 12.2 & & 2.0 & \\
\hline & & Presence of vegetation & 0.8 & & & & & 1.0 & \\
\hline & & Biological Patina & 0.8 & & & & & & \\
\hline & & Bird dropping & 0.8 & & & & & & 0.8 \\
\hline & & Urine stains & 0.8 & & & & & & \\
\hline \multirow{4}{*}{ Presence of deposits } & & Superficial deposit & 0.5 & & & & & & \\
\hline & & florescences /sub-florescences & 0.5 & & & & & & \\
\hline & & Incrustation & 0.5 & & & & & & \\
\hline & & Crust & 0.5 & & & & & & \\
\hline \multirow{9}{*}{ Loss of material } & & Alveolar weathering & 0.8 & 0.8 & & & 4.4 & 15.0 & 3.6 \\
\hline & & Exfoliation & 0.8 & & & & & & \\
\hline & & Scaling & 0.8 & & & & & & \\
\hline & & Erosion & 0.8 & 5.2 & & 7.9 & 2.2 & & 2.6 \\
\hline & & Differential decay & 0.8 & & & & & 10.1 & 1.7 \\
\hline & & isaggregation / pulverization & 0.8 & 0.7 & & & & & \\
\hline & & Pitting & 0.8 & & & & & & \\
\hline & & Fracturing or cracking & 0.8 & & & & & 1.0 & \\
\hline & & $\begin{array}{l}\text { Rubbings/scratches due to } \\
\text { anthropogenic impact }\end{array}$ & 0.8 & & & & & 3.5 & \\
\hline \multirow{4}{*}{$\begin{array}{l}\text { Changing in colour of } \\
\text { surface }\end{array}$} & & Rising front of moisture & 1.0 & 29.0 & 43.0 & 10.3 & 18.8 & & \\
\hline & & Vertical staining & 1.0 & & 0.1 & & & 4.0 & \\
\hline & & Stains & 1.0 & & & & & & \\
\hline & & Soiling & 1.0 & 12.6 & 16 & 9.5 & 10.9 & 15.0 & 5.3 \\
\hline \multirow{4}{*}{$\begin{array}{c}\text { Aesthetical decay } \\
\text { for “addition”(a,b) } \\
\text { or repair/replacement } \\
(\mathrm{c}, \mathrm{d})\end{array}$} & A & Wires/pipelines & 0.5 & & & & & 1.0 & \\
\hline & $\mathrm{B}$ & grafits/paintings & 0.5 & & & & & 1.5 & \\
\hline & $\mathrm{C}$ & Replacement & 1.0 & 3.5 & 4.0 & 1.4 & & 30.1 & 9.6 \\
\hline & $\mathrm{D}$ & $\begin{array}{c}\text { Refacing/repair with mortar or } \\
\text { protective material }\end{array}$ & 1.0 & & & & & & \\
\hline \multicolumn{3}{|c|}{ Decay Index (DI) } & - & 8.5 & 13.4 & 8.1 & 9.7 & 8.7 & 4.2 \\
\hline
\end{tabular}

Table 1. The questionnaire used for the classification of the decay forms and the assessment of the Decay Index. The first column on the left shows the Main category field, the second includes the specific decay forms observed on the surfaces. The third column reports the significance $(W)$ attributed to each specific weathering in the assessment of the Index. The last six columns, numbered from 1 to 6 , show the results of the questionnaire drawing up for six façades belonging to three churches, the Cathedral, St. Francesco d'Assisi, and St. Domenico. The values reported represent the percentage of each surface affected by the specific alteration encountered. 


\begin{tabular}{|c|c|c|c|c|c|c|c|}
\hline Tab. 2a & \multirow{3}{*}{\multicolumn{2}{|c|}{$\begin{array}{l}\text { Decay Index } \\
\text { Range }\end{array}$}} & \multicolumn{5}{|c|}{ Summer sun exposure } \\
\hline \multirow{2}{*}{ Sub-classes } & & & $\begin{array}{c}\text { class } 1 \\
0-51 \\
\end{array}$ & $\begin{array}{l}\text { class } 2 \\
52-102 \\
\end{array}$ & $\begin{array}{c}\text { class } 3 \\
103-153\end{array}$ & $\begin{array}{c}\text { class } 4 \\
154-204\end{array}$ & $\begin{array}{c}\text { class } 5 \\
205-255\end{array}$ \\
\hline & & & \multicolumn{5}{|c|}{ Frequency (number of façades) } \\
\hline 1 & 1.23 & 3.73 & 1 & 1 & 5 & 5 & 22 \\
\hline 2 & 3.73 & 6.23 & 1 & 0 & 7 & 8 & 65 \\
\hline 3 & 6.23 & 8.73 & 2 & 0 & 2 & $5 *$ & $43^{* *}$ \\
\hline 4 & 8.73 & 11.23 & 0 & 0 & 3 & 4 & 6 \\
\hline 5 & 11.23 & 13.73 & 0 & 0 & 1 & 0 & 4 \\
\hline
\end{tabular}

\begin{tabular}{|c|cccc|}
\hline Tab. 2b & \multicolumn{4}{|c|}{ Wind class } \\
\hline $\begin{array}{c}\text { Summer sun exposure classes of } \\
\text { Tab. 3a (for DI=3) }\end{array}$ & $\mathbf{1}$ & $\mathbf{2}$ & $\mathbf{3}$ & $\mathbf{4}$ \\
\hline $4^{*}$ & 3 & 0 & 2 & 0 \\
\hline $5^{* *}$ & 12 & 20 & 5 & 6 \\
\hline
\end{tabular}

Table 2 - Data matrix between the sun exposure and the DI values in summer. The sun exposure is considered over five classes, from 0 to 255 (Table 2a); the data with asterisk are compared to the wind exposure (Table $2 b)$. 


\begin{tabular}{|c|c|c|c|c|c|c|c|}
\hline Tab. 3a & \multirow{3}{*}{\multicolumn{2}{|c|}{$\begin{array}{c}\text { Decay index } \\
\text { Range }\end{array}$}} & \multicolumn{5}{|c|}{ Winter sun exposure } \\
\hline \multirow{2}{*}{ Subclass } & & & $\begin{array}{c}\text { class } 1 \\
0-51\end{array}$ & $\begin{array}{l}\text { class } 2 \\
52-102 \\
\end{array}$ & $\begin{array}{c}\text { class } 3 \\
103-153 \\
\end{array}$ & $\begin{array}{c}\text { class } 4 \\
154-204 \\
\end{array}$ & $\begin{array}{c}\text { class } 5 \\
205-255 \\
\end{array}$ \\
\hline & & & \multicolumn{5}{|c|}{ Frequency } \\
\hline 1 & 1.23 & 3.73 & 7 & 3 & 11 & 4 & 8 \\
\hline 2 & 3.73 & 6.23 & 15 & 14 & 25 & 7 & 20 \\
\hline 3 & 6.23 & 8.73 & $4^{\mathrm{a}}$ & $12^{\mathrm{b}}$ & $15^{c}$ & $8^{d}$ & $13^{e}$ \\
\hline 4 & 8.73 & 11.23 & 5 & 2 & 4 & 1 & 1 \\
\hline 5 & 11.23 & 13.73 & 1 & 1 & 2 & 0 & 1 \\
\hline
\end{tabular}

\begin{tabular}{|c|cccc|}
\hline Tab. 3b & \multicolumn{5}{|c|}{ Wind class } \\
\hline $\begin{array}{c}\text { Winter sun exposure class of } \\
\text { Tab. 3a (for DI=3) }\end{array}$ & $\mathbf{1}$ & $\mathbf{2}$ & $\mathbf{3}$ & $\mathbf{4}$ \\
\hline $1^{\text {a }}$ & 0 & 1 & 2 & 1 \\
\hline $2^{\mathrm{b}}$ & 2 & 1 & 2 & 7 \\
\hline $3^{\mathrm{c}}$ & 7 & 4 & 2 & 2 \\
\hline $4^{\mathrm{d}}$ & 1 & 7 & 0 & 0 \\
\hline $5^{\mathrm{e}}$ & 6 & 6 & 1 & 0 \\
\hline
\end{tabular}

Table 3- Data matrix between the sun exposure and the $D I$ values in winter. As for the data in summer, the sun exposure is considered over five classes, from 0 to 255 (Table 2a). The data with letters as apex are compared with the wind exposure (Table $3 b)$. 


\section{Figure captions}

Figure 1. Map of the Matera historical centre showing the façades investigated through the on-site survey.

Figure 2. The Calcarenite of Gravina sampled at Matera, as viewed in thin section (view at polarization microscope, Nicol +) (after Sileo, 2012 [27]).

Figure 3. Some of the weathering typologies surveyed in the Sassi site: a) Biological colonization from the Cathedral; b) Presence of vegetation from the Palazzo Santoro; c) Bird dropping from St. Domenico Church; d) Alveolar weathering from St. Giovanni Battista Church; e) Exfoliation from St. Chiara Church; f) Erosion from St. Giovanni Battista Church; g) Differential decay from St.Francesco d'Assisi Church; h) Disaggregation/pulverization from the lateral façade of St. Domenico Church.

Figure 4. Some of the weathering typologies surveyed in the Sassi site: a) Fracturing/cracking from the bell tower of the St. Domenico Church; b) Rubbings/scratches from the St. Domenico Church; c) Rising of moisture from the lateral façade of the Cathedral; d) Soiling from the St. Giovanni Battista Church; e) Wires/pipelines from the St. Domenico Church; f) Grafitis/paintings from the St. Domenico Church; g) Replacement from the St. Giovanni Battista Church; h) Refacing/repair with mortar from the St. Chiara Church.

Figure 5. The decay forms over the surfaces of three monuments: a) Cathedral main front; b) St. Francesco Church main façade; c) St. Domenico Church lateral façade.

Figure 6. Statistical data regarding the area of the façades. Most of the walls (73\%) show an area that does not overpass 40 square meters.

Figure 7. The area of the Sassi site characterized by hot and cold spot of DI. The KDE colour depicts the $D I$ values: the brownish-reddish colour refers to the highest $D I$ values. The figure also shows the relationship between the KDE and the wind exposure days for each façade represented by the thickness of the black segments. As can be argued from the rose diagram, the main winds blow from the north and north-east directions.

Figure 8. Frequency of wind directions (2012-2013) in rainy days with the data on rainfall (figure shows the number of rainy days). 
Figure 1

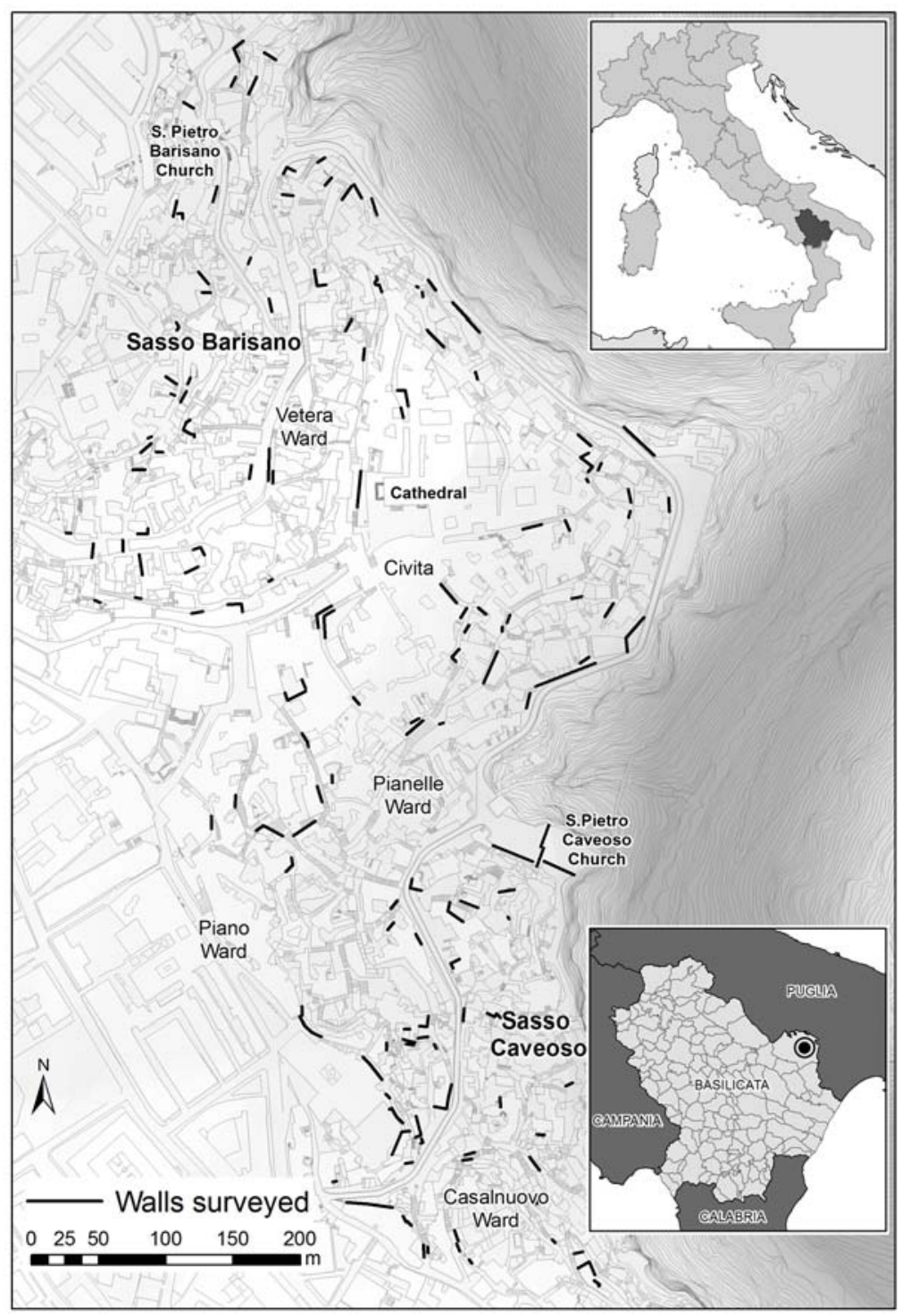


Figure 2

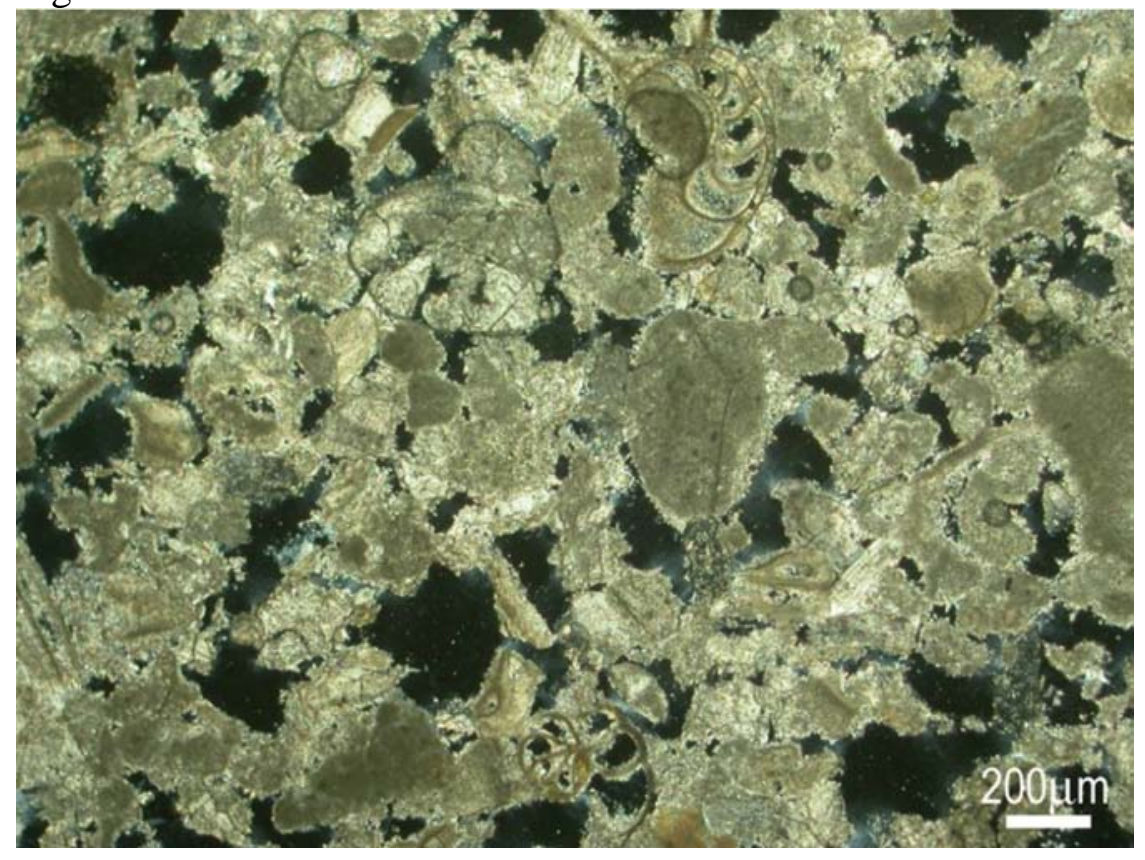


Figure 3
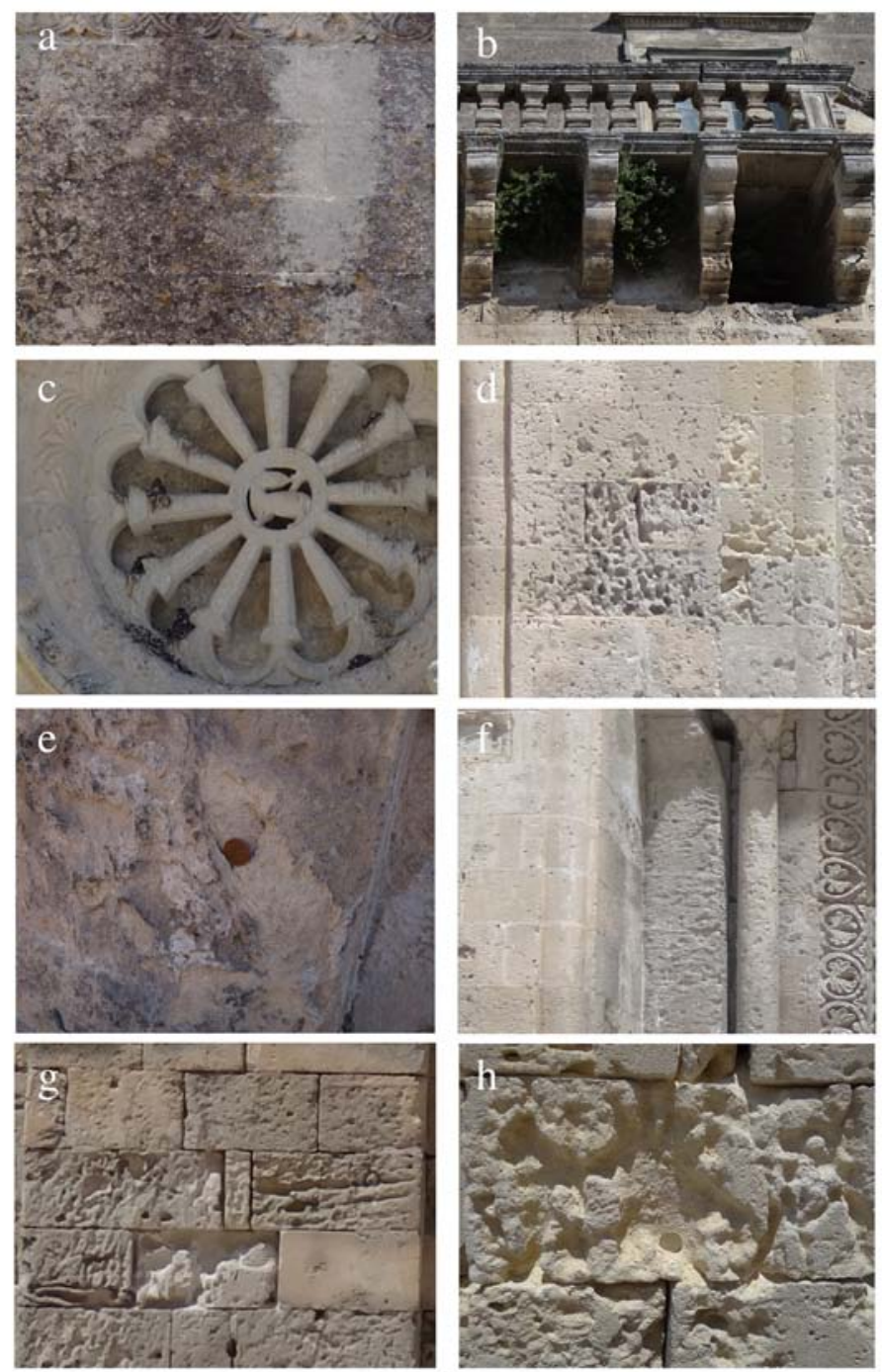
Figure 4
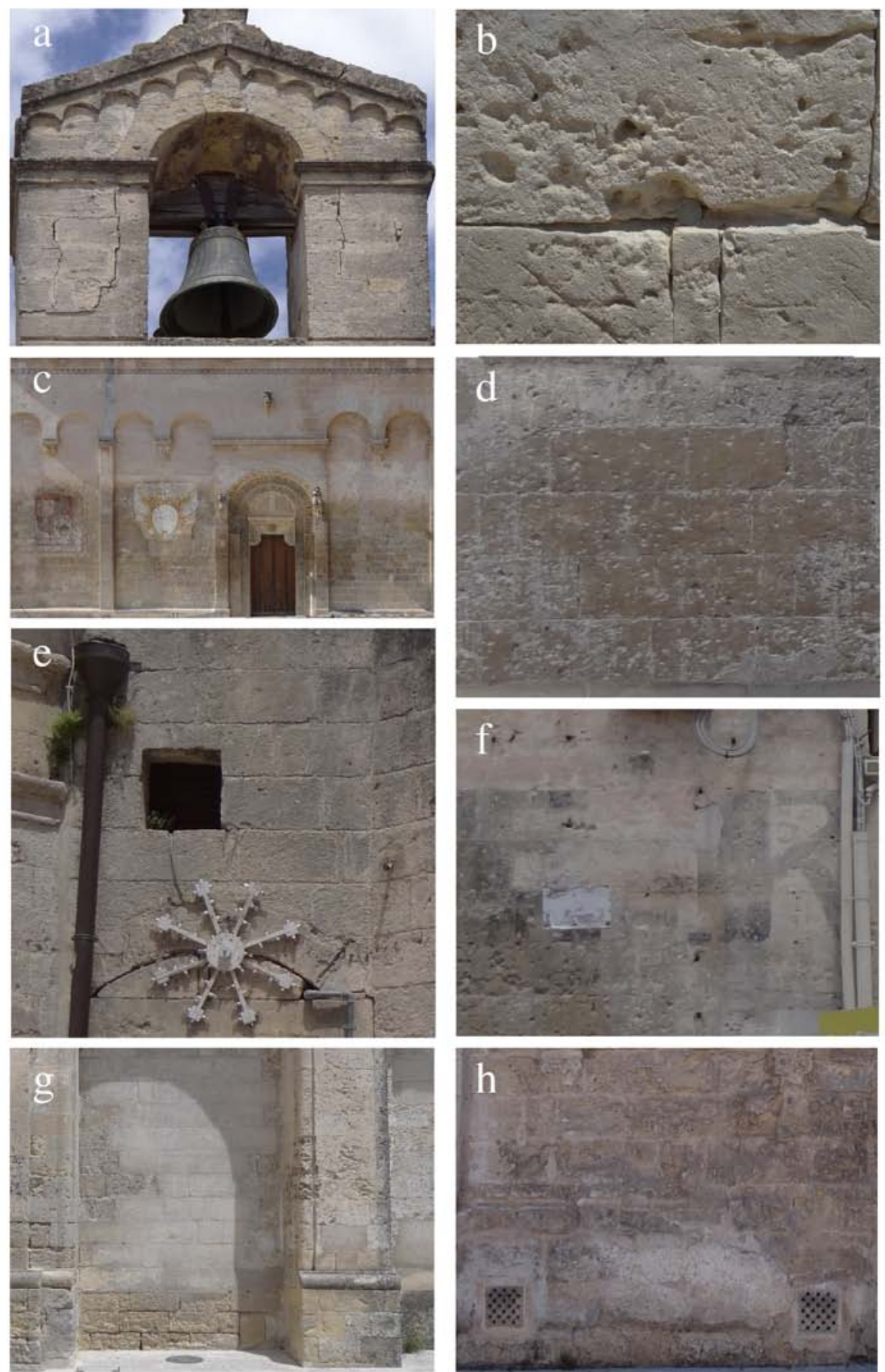
Figure 5
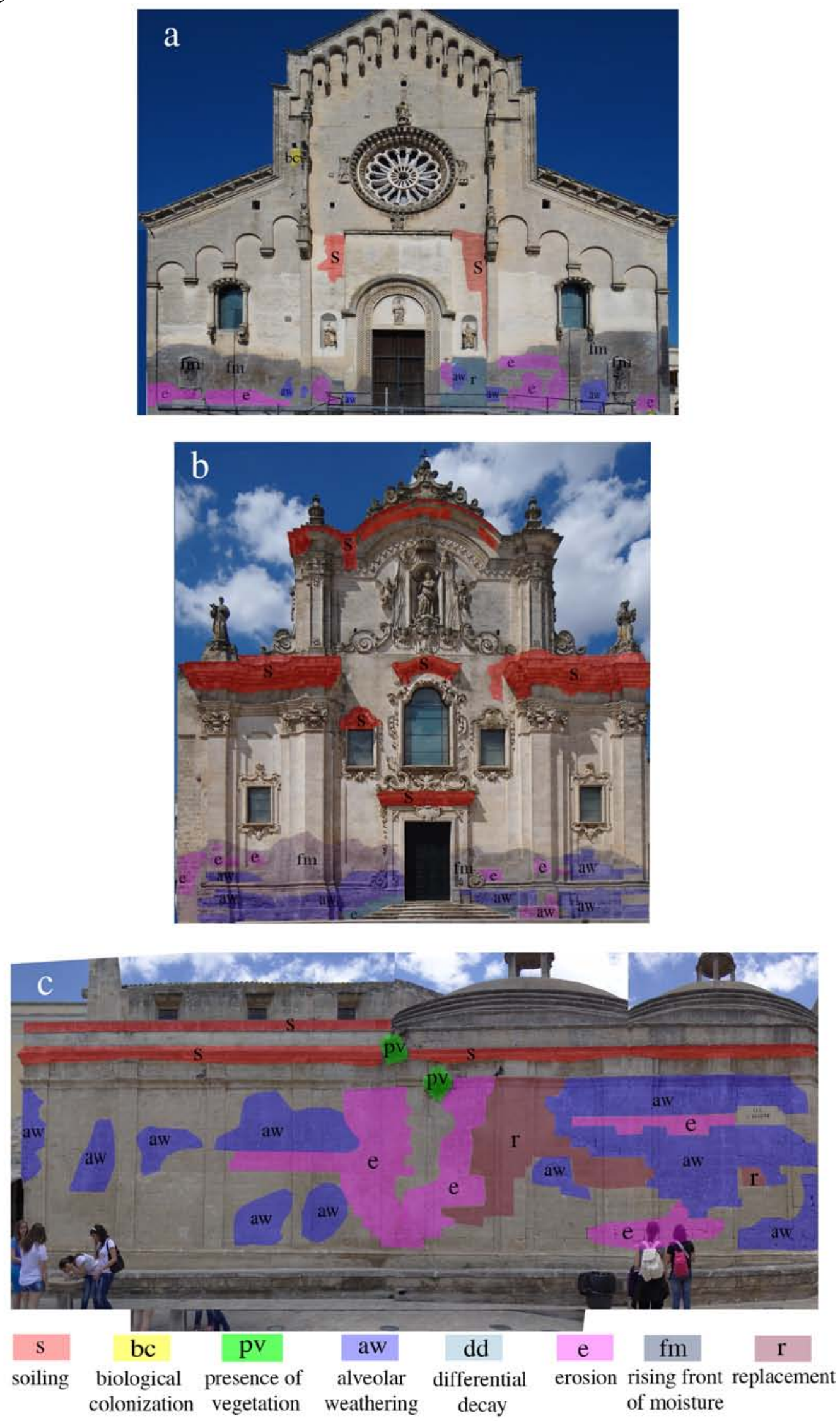
Figure 6

\section{areal distribution}

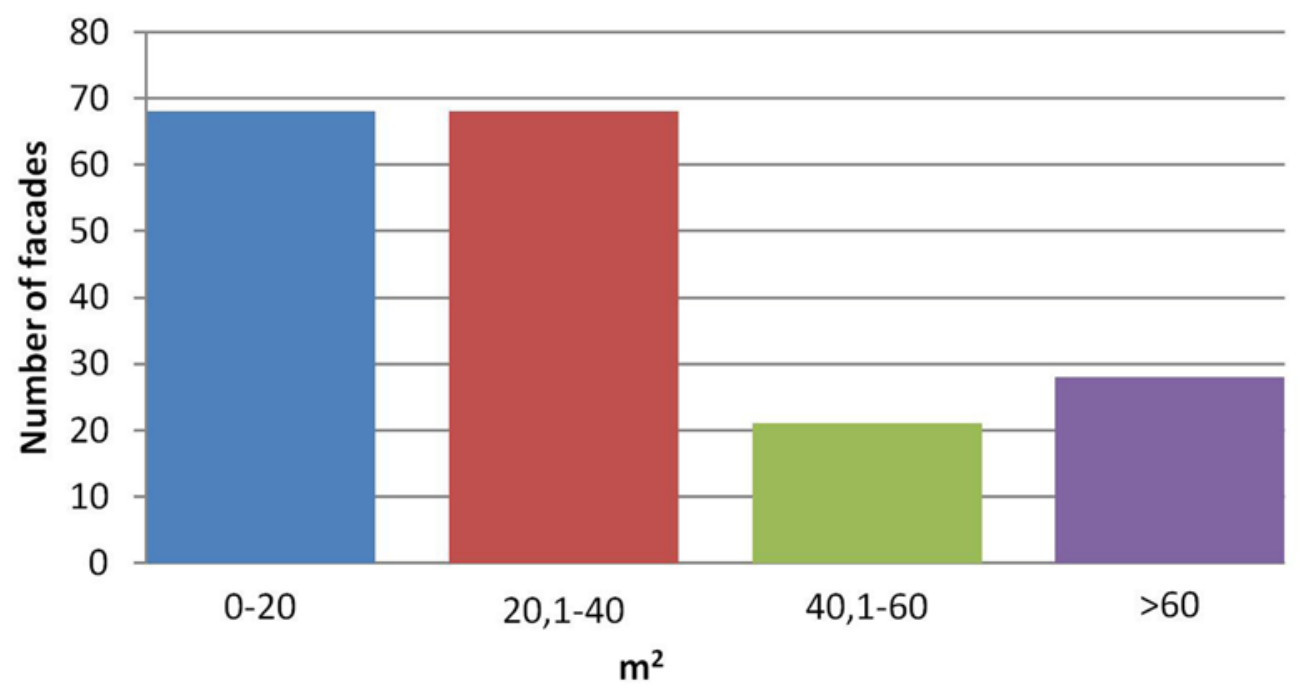


Figure 7

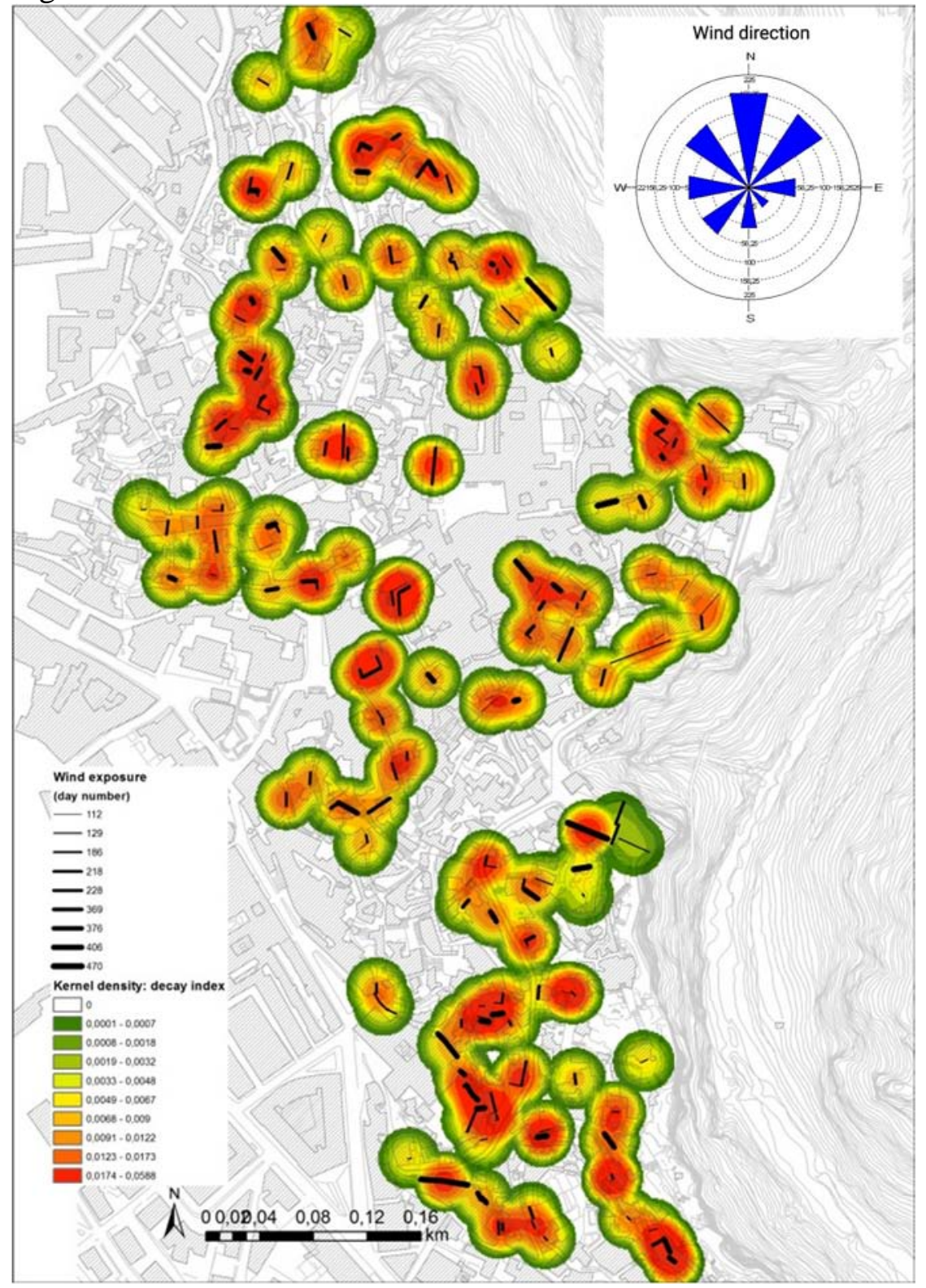

